OPEN ACCESS

Edited by:

Adam Schikora,

Justus Liebig University Giessen,

Germany

Reviewed by:

Fanhong Meng,

Texas A\&M University, USA

Harsh Bais,

University of Delaware, USA

*Correspondence:

M. Kaleem Abbasi,

Department of Soil and Environmental

Sciences, The University of Poonch,

Rawalakot, Azad Jammu and

Kashmir, Pakistan

mkaleemabbasi@gmail.com

Specialty section

This article was submitted to

Plant-Microbe Interaction, a section of the journal Frontiers in Microbiology

Received: 24 December 2014 Accepted: 24 February 2015

Published: 17 March 2015

Citation:

Majeed A, Abbasi MK, Hameed S, Imran A and Rahim N (2015) Isolation and characterization of plant growth-promoting rhizobacteria from wheat rhizosphere and their effect on plant growth promotion.

Front. Microbiol. 6:198. doi: 10.3389/fmicb.2015.00198

\section{Isolation and characterization of plant growth-promoting rhizobacteria from wheat rhizosphere and their effect on plant growth promotion}

\author{
Afshan Majeed ${ }^{1}$, M. Kaleem Abbasi ${ }^{1 *}$, Sohail Hameed ${ }^{2}$, Asma Imran $^{2}$ and \\ Nasir Rahim ${ }^{1}$ \\ ${ }^{1}$ Department of Soil and Environmental Sciences, The University of Poonch, Rawalakot, Azad Jammu and Kashmir, \\ Pakistan, ${ }^{2}$ National Institute for Biotechnology and Genetic Engineering, Faisalabad, Pakistan
}

The present study was conducted to characterize the native plant growth promoting (PGP) bacteria from wheat rhizosphere and root-endosphere in the Himalayan region of Rawalakot, Azad Jammu and Kashmir (AJK), Pakistan. Nine bacterial isolates were purified, screened in vitro for PGP characteristics and evaluated for their beneficial effects on the early growth of wheat (Triticum aestivum L.). Among nine bacterial isolates, seven were able to produce indole-3- acetic acid in tryptophan-supplemented medium; seven were nitrogen fixer, and four were able to solubilize inorganic phosphate in vitro. Four different morphotypes were genotypically identified based on IGS-RFLP fingerprinting and representative of each morphotype was identified by $16 \mathrm{~S}$ rRNA gene sequencing analysis except Gram-positive putative Bacillus sp. Based on 16S rRNA gene sequence analysis, bacterial isolates AJK-3 and AJK-9 showing multiple PGPtraits were identified as Stenotrophomonas spp. while AJK-7 showed equal homologies to Acetobacter pasteurianus and Stenotrophomonas specie. Plant inoculation studies indicated that these Plant growth-promoting rhizobacteria (PGPR) strains provided a significant increase in shoot and root length, and shoot and root biomass. A significant increase in shoot $\mathrm{N}$ contents (up to $76 \%$ ) and root $\mathrm{N}$ contents (up to $32 \%$ ) was observed over the un-inoculated control. The study indicates the potential of these PGPR for inoculums production or biofertilizers for enhancing growth and nutrient content of wheat and other crops under field conditions. The study is the first report of wheat associated bacterial diversity in the Himalayan region of Rawalakot, AJK.

Keywords: biofertilizers, diversity, plant growth-promoting rhizobacteria, 16S rRNA, wheat

\section{Introduction}

Chemical fertilizers are generally used to supply essential nutrients to the soil-plant system throughout the world. However, the prices, availability, and the environmental concerns of chemical fertilizers especially the $\mathrm{N}$ fertilizers are real issues of today's agriculture. Application of chemical fertilizers in slopping landscapes under high annual rainfall normally exist in the mountain ecosystem of the Hindu Kush Himalayan (HKH) region may not be effective because 
of surface runoff and leaching. Therefore, there is an urgent need to find alternative strategies that can ensure competitive crop yields, provide environmental safety, and protection while maintain long term ecological balance in agro-ecosystem. Use of microbial inoculants or plant growthpromoting rhizobateria (PGPR) for the enhancement of sustainable agricultural production is becoming a more widely accepted practice in intensive agriculture in many parts of the world.

Plant growth-promoting rhizobacteria are free-living soil bacteria that aggressively colonize the rhizosphere/plant roots, and enhance the growth, and yield of plants when applied to seed or crops (Kumar et al., 2014). The plant growth promoting (PGP) effect of the PGPR is mostly explained by the release of metabolites directly stimulating growth. Several mechanisms have been postulated to explain how PGPR benefit the host plant. These include: (a) the ability to produce plant growth regulators or phytohormones such as indole acetic acid (IAA), cytokinins, and gibberellins (Glick, 1995; Marques et al., 2010); (b) enhancing asymbiotic $\mathrm{N}_{2}$ fixation (Sahin et al., 2004; Khan, 2005); (c) solubilizing inorganic phosphate and mineralization of organic phosphate and/ or other nutrients (Glick, 1995; Jeon et al., 2003); (d) antagonistic effect against phytopathogenic microorganisms by production of siderophores, the synthesis of antibiotics, enzymes, and/or fungicidal compounds, and competition with detrimental microorganisms (Dey et al., 2004; Lucy et al., 2004).

Interest in the beneficial rhizobacteria associated with cereals has increased recently and several studies clearly demonstrated the positive and beneficial effects of PGPR on growth and yield of different crops especially wheat at different environment under variable ecological conditions (Ozturk et al., 2003; Marques et al., 2010; Mehnaz et al., 2010; Zhang et al., 2012). Inoculation with Pseudomonas fluorescens showed a significant increase in root weight $19-43 \%$, number of tillers per plant $10-21 \%$, grain yield $15-43 \%$, and straw yield $22-39 \%$ of wheat compared to un-inoculated plants (Shaharoona et al., 2008). Moreover, inoculation with PGPR strain Azotobacter saved 25$30 \mathrm{~kg} \mathrm{~N} \mathrm{ha}{ }^{-1}$ chemical fertilizer (Narula et al., 2005). More recently, Kumar et al. (2014) conducted experiments on wheat under pot and field condition to examine the effect of PGPRs on the growth and yield of wheat and found that triple combination of strains B. megaterium, A. chlorophenolicus, and Enterobacter significantly increased $17.5,79.8,78.6$, and $26.7 \%$ plant height, grain yield, straw yield, and test weight under pot condition and also $29.4,27.5,29.5$, and $17.6 \%$ under field condition, respectively.

Knowledge of the native bacterial population, their characterization, and identification is required for understanding the distribution and diversity of indigenous bacteria in the rhizosphere of specific crops (Keating et al., 1995; Chahboune et al., 2011). With increasing awareness about the-chemical-fertilizersbased agricultural practices, it is important to search for regionspecific microbial strains which can be used as a growth promoting/enhancing inoculum to achieve desired crop production (Deepa et al., 2010). Recently, the bacterial diversity in the forest soil of Kashmir, India was investigated and reported
(Ahmad et al., 2009) but no data is available regarding the rhizosphere microbiome of wheat native to this area. Wheat being a staple food has special importance in the economy of the country.

Keeping in mid the study was planned to isolate the native strains from rhizosphere and endo-rhizosphere of wheat grown on different soils of Rawlakot, AJK. These bacteria were characterized and screened in vitro for PGP potentials and representative isolates were identified by $16 \mathrm{~S}$ rRNA sequence analysis. Furthermore, the PGP potential was evaluated in vivo under axenic conditions and effect on the growth, and $\mathrm{N}$ contents of wheat at early growth stage was investigated.

\section{Materials and Methods}

\section{The Study Site}

The study site is located in an experimental farm of the University of the Poonch Rawalakot, Azad Jammu and Kashmir (AJK), Pakistan at the Faculty of Agriculture Rawalakot. Rawalakot is located at latitude $33^{\circ} 51^{\prime} 32.18^{\prime \prime} \mathrm{N}$, longitude $73^{\circ} 45^{\prime} 34.93^{\prime \prime} \mathrm{E}$, and an elevation of $1638 \mathrm{~m}$ above the sea level in the northeast of Pakistan under the foothills of great Himalayas. The topography is mainly hilly and mountainous with valleys and stretches of plains. The area is characterized by a temperate subhumid climate with annual average rainfall ranging from about $500-2000 \mathrm{~mm}$, most of which is irregular and falls with intense storms during monsoon and winter. The monthly mean temperature ranges from a minimum of $0^{\circ} \mathrm{C}$ to a maximum of $22^{\circ} \mathrm{C}$ accompanied by a severe cold and snow fall in winter. The soil used in the study $(0-15 \mathrm{~cm})$ was silt loam in texture (Organic carbon $9.5 \mathrm{~g} \mathrm{~kg}^{-1}$, total $\mathrm{N} 1.02 \mathrm{~g} \mathrm{~kg}^{-1}$, available P $2.5 \mathrm{mg} \mathrm{kg}^{-1}$, available $\mathrm{K}_{5} \mathrm{mg} \mathrm{kg}^{-1}$ and $\mathrm{pH}$ 6.7).

\section{Sample Collection and Isolation of Bacteria}

Wheat (Triticum aestivum L.) variety Inqlab-91, plant samples were collected from Research farm fields of Faculty of Agriculture Rawalakot along with bulk rhizospheric soil. Samples were placed individually in plastic bags and brought to National Institute of Biotechnology and Genetic Engineering (NIBGE), Faisalabad for isolation of bacteria. Rhizospheric bacteria were isolated from $1 \mathrm{~g}$ soil tightly adhering to the root by serial dilution plating on Luria-Bertani (LB) agar plates as described (Somasegaran and Hoben, 1994). Endophytic bacteria were isolated by serial dilution plating of sterilized crushed root samples on LB agar plates as described (Hameed et al., 2004). The plates were incubated at $28 \pm 2{ }^{\circ} \mathrm{C}$ till the appearance of bacterial colonies. Individual colonies were picked and streaked on LB plates for further purification.

\section{Biochemical Characterization}

Colony morphology, size, color, shape, gum production, and growth pattern were recorded after $24 \mathrm{~h}$ of growth on LB agar plates at $28 \pm 2{ }^{\circ} \mathrm{C}$ as described by Somasegaran and Hoben (1994). Cell size and motility was observed by light microscopy. Acid/alkali production was tested on LB agar plates containing $0.025 \%(\mathrm{w} / \mathrm{v})$ bromothymol blue as $\mathrm{pH}$ indicator. The Gram 
reaction was performed as described by Vincent and Humphrey (1970). Amino-peptidase and cytochrome oxidase tests were performed by using commercially available strips (Merck, Darmstadt, Germany). Catalase production was checked by placing a drop of $\mathrm{H}_{2} \mathrm{O}_{2}$ onto the bacterial colony on a glass slide.

\section{Molecular Characterization}

Total genomic DNA of bacterial strains was extracted by alkaline lysis method (Maniatis et al., 1982) with slight modifications. DNA concentration was determined by DNA fluorometer (DYNA Quant ${ }^{\mathrm{TM}}$ 200). On the basis of cell and colony morphology, nine different morphotypes were identified from rhizosphere and endosphere of wheat. These morphotypes were subjected to restriction fragment length polymorphism of IGS to distinguish among these genotypes. 16S rRNA$23 \mathrm{~S}$ rRNA intergenic spacer region was amplified as described (Laguerre et al., 1996) using forward primer FGPS-1490 (5TGGGGCTGGATCACCTCCTT -3) and reverse primer FGPS132 (5- CCGGGTTTCCCCATTCGG-3). The PCR-product was restricted using BamHI and HindIII bacterial isolates were clustered. A representative of each IGS-RFLP type was identified by analysis of $16 \mathrm{~S}$ rRNA gene sequence. The complete $1.5-\mathrm{kb}$ $16 \mathrm{~S}$ rRNA region was amplified using the universal bacterial $16 \mathrm{~S}$ rRNA primers $\mathrm{P} 1$ a forward primer $\left(\mathrm{P} 1=5^{\prime}-\right.$ cgggatccAGAGTTTGATCCTGGTCAGAACGAACGCT - $3^{\prime}$ ) and P6; a reverse primer $\left(\mathrm{P} 6=5^{\prime}\right.$ - cgggatccTACGGCTACCTTGTTACGACTTCACCCC - $3^{\prime}$ ) which correspond to Escherichia coli positions 8-37 and 1479-1506, respectively, and amplifies 1500 bp full gene fragment (Tan et al., 1997).

The PCR amplification of the target sequence was done as described (Imran et al., 2010). Amplified PCR products of $16 \mathrm{~S}$ ribosomal gene were confirmed on $1 \%$ agarose gel, purified using QIAquick PCR purification kit (QIAGEN) and cloned into E. coli TOP10 (Invitrogen). Plasmids DNA was isolated using Rapid plasmid mini Prep kit (Marligen Bioscience) and restricted with EcoRI and BamHI for the confirmation of transformed amplicons. Cloned PCR products were sequenced commercially by Macrogen (Korea).

The obtained gene sequences were compared with others in the Gen Bank databases using the NCBI BLAST at http://www.ncbi.n1m.nih.gov/blast/Blast.cgi. Sequences were submitted to NCBI GenBank data base and accession numbers were obtained.

\section{Bioassays for Plant Growth Promoting Traits Solubilization of Insoluble Phosphate and Zinc}

Each bacterial culture was spot inoculated in the center of agar plates containing tricalcium phosphate as insoluble phosphate source (Pikovskaya, 1948) and onto LGI medium (Cavalcante and Döbereiner, 1988) supplemented with $0.1 \%$ zinc oxide and zinc sulfate. The plates were incubated at $28 \pm 2{ }^{\circ} \mathrm{C}$ for 7-10 days and observed for the formation of halo zone around the colonies. P-solubilization was quantified by Phosphomolybdate blue color method using spectrophotometer $(\lambda=882)$ as described by Murphy and Riley (1962). The experiment was repeated twice with three replicates each and mean was calculated.

\section{Production of Indole-3-Acetic Acid}

Bacterial cultures were grown in Okon et al.'s (1977) malate medium supplemented with tryptophan $(100 \mathrm{mg} / \mathrm{L})$ as the precursor of IAA and compared to those grown without the addition of tryptophan precursor. IAA production was determined using colorimetric methods (Gordon and Weber, 1951) and quantified on HPLC using ethyl acetate oxidation method (Tien et al., 1979). The experiment was repeated twice with three replicates each and mean was calculated.

\section{Nitrogen Fixation}

Nitrogenase activity was detected by acetylene reduction/ethylene production assay as described earlier (Mirza et al., 2001). Pure bacterial colonies were inoculated into NFM (Nitrogen Free Malate) semisolid medium vials and incubated at $28 \pm 2^{\circ} \mathrm{C}$ for $48 \mathrm{~h}$. Acetylene $(10 \% \mathrm{v} / \mathrm{v})$ was injected to the vials, incubated at $28 \pm 2{ }^{\circ} \mathrm{C}$ for $16 \mathrm{~h}$ and $100 \mu \mathrm{L}$ of gas samples from the vials were analyzed on a gas chromatograph (Thermoquest, Trace G.C, Model K, Rodono Milan, Italy) equipped with a Porapak Q column and a $\mathrm{H}_{2}$-flame ionization detector (FID) using conditions described in Hardy et al. (1973). The experiment was repeated twice with three replicates each and mean was calculated.

\section{Plant Inoculation and Root Colonization Assays}

Effect of bacterial inoculation on plant growth was examined on wheat variety Inqalab-91 in a growth room experiment. The Azospirillum brasilense strain Er-20 (Mirza et al., 2000) was used as positive control while un-inoculated plants served as negative control. Bacterial cultures were grown in $50 \mathrm{~mL}$ falcon tubes filled with $25 \mathrm{~mL}$ LB broth and were kept on shaker at $200 \mathrm{rpm}$ for $16 \mathrm{~h}$. Seeds were germinated on water agar plates and transferred aseptically to plant growth pouches (Weaver and Frederick, 1982) after 4 days of seedling emergence. Before transferring the germinated seeds to the pouches (autoclaved), $20 \mathrm{~mL}$ of $1 / 2$ strength Hoagland's nutrient solution was poured in the pouches. The un-inoculated pouches were watered with full strength Hoagland (with N, P) while inoculated pouches received full strength Hoagland without $\mathrm{N}$ and $\mathrm{P}$ along-with $1 \mathrm{~g}$ inorganic tri-calcium phosphate as sole P-source. After 2 days of seedling transplant, $1 \mathrm{~mL}$ inoculum (cells suspended in $0.85 \%$ saline; $\mathrm{OD}=0.45$ ) was applied at the base of each seedling. The un-inoculated pouches were supplied with same amount of sterile saline. Two seedlings were maintained per growth pouch and placed in growth chamber at $20-22^{\circ} \mathrm{C}$ with a day length of $12 \mathrm{~h}$ and relative humidity was set at $70 \%$. The experiment was set up in randomized complete design (CRD) using 10 replicate pouches per treatment. Plants were harvested 60 days after transplantation and data was recorded for shoot and root length, shoot and root dry weight, and shoot and root $\mathrm{N}$ contents. Total nitrogen contents of the plants were determined by the Kjeldahl method (Keeney and Nelson, 1982).

Root colonization potential of inoculated bacteria was determined at every 15 day using serial dilution plating technique 
on LB agar and number of viable cells was estimated as colony forming units (CFU) as described in Somasegaran and Hoben (1994) on LB agar plates.

\section{Statistical Analysis}

The data were subjected to analysis of variance using statistical program xxx (MSTATC, 1990). The differences among various treatment means were compared using the least significant differences test (LSD) at 5\% $(P \leq 0.05)$ probability level (Steel and Torrie, 1980).

\section{Results}

\section{Culturable Bacteria in the Rhizosphere and Endosphere of Wheat}

Bacteria were obtained both from rhizospheric portion as well as root interior of wheat. Six bacteria were obtained from wheat rhizosphere soil while three from root interior (Table 1). The bacteria showed gummy, white-to milky white colonies with variable sizes and margins (Table 1) on LB agar plates. The cells were mostly motile, rod shaped showing Gram-negative reaction except AJK-4 and AJK-8 both of which were tentatively identified as Bacillus sp. based on their colony and cell morphologies and Gram reaction.

\section{Identification of Bacteria}

Nine wheat rhizo/endophytic bacteria yielded four IGS patterns. Among these four patterns, one comprising of Bacillus sp. was not sequenced but from other three types, one strain each was sequenced based on $16 \mathrm{~S}$ rRNA gene. The PGPR isolate AJK-3 was identified as Stenotrophomonas rhizophila strain having $99 \%$ similarity with the reported gene sequence. AJK-7 showed 98\% similarity with Acetobactor pasteurianus. However, isolate AJK-9 95\% similarity with Stenotrophomonas specie. The new isolate, AJK-9 had many of its beneficial characteristics resembling Stenotrophomonas strain AJK3 , hence may be considered as a Stenotrophomonas species. Nucleotide accession number for strain AJK-9, AJK-7, and AJK-3 are GQ130134, GQ130133, and GQ130132, respectively.

\section{Plant Growth Promoting Potential}

In vitro plant growth promotion traits of the rhzio/endophytic bacteria are described in Table 2. Seven out of nine bacterial isolates (except isolates AJK-2, AJK-5) were able to produce IAA with a range of $0.27-77.98 \mu \mathrm{g} \mathrm{ml}^{-1}$ in the presence of IAA precursor tryptophan. Stenotrophomonas sp. strain AJK-9 produced maximum IAA $\left(77.98 \mu \mathrm{g} \mathrm{ml}^{-1}\right)$ followed by S. rhizophila strain AJK-3. The isolates AJK-1, AJK-2, AJK-3, and AJK-9 produced IAA even without IAA precursor tryptophan.

Acetylene reduction assay (ARA) showed seven isolates including both rhizosphere and endophytic bacteria have the nitrogenase activity ranging from 1.44 to $7.89 \mu \mathrm{mol} \mathrm{C}_{2} \mathrm{H}_{4} \mathrm{mg}$ protein/h. Putative Stenotrophomonas sp. isolate AJK-6 showed maximum ARA.

Four bacteria including three rhizospheric (AJK-1, AJK-2, AJK-3) and one endophytic (AJK-8) were able to form clear zone on Pikovskaia's agar plates after 7 days of incubation. When quantified spectrophotometrically, maximum $\mathrm{P}$ was solubilized by putative Bacillus sp. AJK-8 which was an endophytic strain and formed a clear zone of $3 \mathrm{~mm}$ diameter on Pikovskaia's agar plate (Figure 1). The range of P-solubilization varied from 2 to $19 \mu \mathrm{g} / \mathrm{mL}$. We could not found any bacteria able to solubilized zinc oxide or zinc sulfate during this study.

\section{Root Colonization Potential}

Bacterial population size was determined by plate count method on LB agar at different time intervals. We observed that all rhizospheric as well as endophytic bacteria were able to colonize wheat plant roots and showed persistence in the rhizosphere up to 60 days after inoculation (Figure 2). Plants were grown in growth pouches for this experiment; hence, we could not determine the population size at maturity. Maximum colonization was recorded between 30 and 45 days post inoculation. Rhizosphere strain AJK-3 showed maximum number of bacteria at all times as compared to other bacterial isolates.

\section{Plant Growth Parameters}

The bacterial isolates exerted a significant influence on wheat growth characteristics (Table 3; Figure 3). Comparisons were made among Azospirillum (ER-20) inoculated positive control and a non-inoculated control (with Hoagland $\mathrm{N}$ and $\mathrm{P}$ ).

TABLE 1 | Morphological characteristics of bacterial isolates from the wheat rhizosphere in the mountain region of Rawalakot, Azad Jammu and Kashmir (AJK), Pakistan.

\begin{tabular}{|c|c|c|c|c|c|c|c|}
\hline Strains & Isolated from & Colony size and shape & Colony color & Acid/alkali production on BTB & Cell motility & Cell shape & Gram reaction \\
\hline AJK-1 & $\mathrm{RHS}$ & Small, Wavy & White & Neutral & Highly motile & Small rods & - \\
\hline AJKK-2 & $\mathrm{RHS}$ & Small, Round & Milky white & Neutral & Motile & Medium rods & - \\
\hline AJK-3 & $\mathrm{RHS}$ & Large, Round & Dark Yellow & Acidic & Highly motile & Oval & - \\
\hline AJK-4 & $\mathrm{RHS}$ & Medium, Wavy & Off-white & Neutral & Slowly motile & oval & + \\
\hline AJK-5 & $\mathrm{RHS}$ & Small, Round & Off-white & Acidic & Slowly motile & Medium rods & - \\
\hline AJK-6 & $\mathrm{RHS}$ & Large, Round & Dark yellow & Acidic & Highly motile & Small rods & - \\
\hline AJK-7 & $\mathrm{Rl}$ & Medium, Round & Milky white & Neutral & Highly motile & Thin rods & - \\
\hline AJK-8 & $\mathrm{Rl}$ & Medium, Round & Milky white & Neutral & Highly motile & Small rods & + \\
\hline AJK-9 & $\mathrm{RI}$ & Small, Round & Milky white & Neutral & Highly motile & Medium rods & - \\
\hline
\end{tabular}

RHS, Rhizosphere soil; RI, Root interior. 


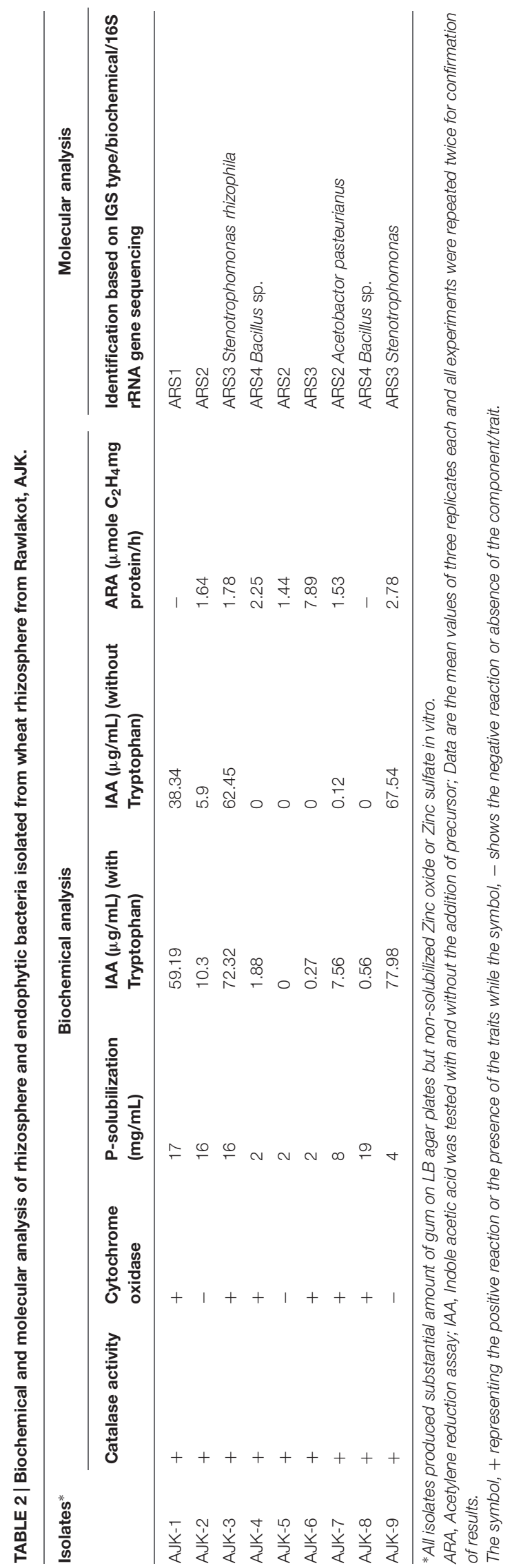

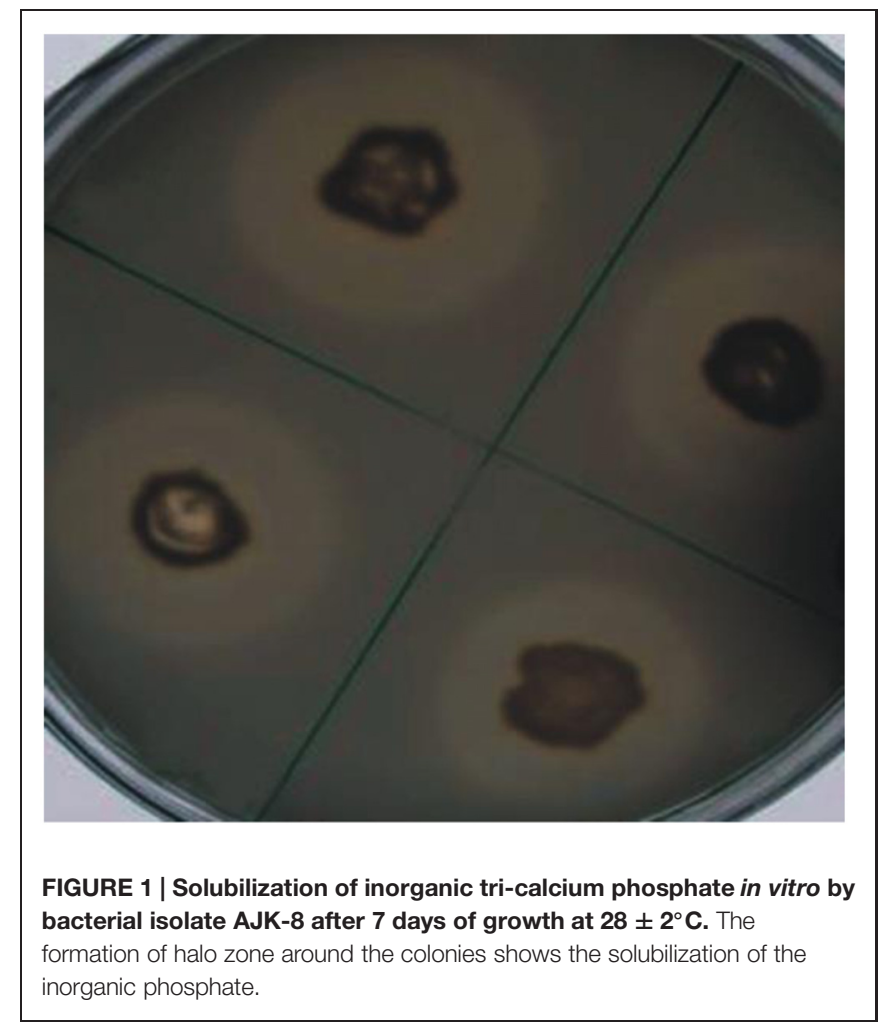

The relative increase in shoot and root length due to bacterial isolates ranged between $25-45 \%$ and $29-52 \%$, respectively, over the un-inoculated control whilst the corresponding increase in the shoot and root biomass ranged between $2-62 \%$ and $100-172 \%$, respectively (Figures $3 A$ A,B). Similarly, bacterial isolates significantly increased $\mathrm{N}$ content both in shoot and root compared to un-inoculated control and Er20 (Figure 4A). The relative increase varied between $22-76 \%$ for shoot and $10-32 \%$ for root over the un-inoculated control. The correlation between root length and shoot $\mathrm{N}$ contents was positive and significant, i.e., $R^{2}=0.67$ (Figure 4B). The efficacy of different isolates for growth characteristics was variable. Bacterial isolates AJK-2, AJK-9, AJK-3, and AJK-7 performed significantly better than others. Overall, the effect of bacterial inoculation was more pronounced on root than shoot.

\section{Discussion}

The PGP potential of Rhizobacteria isolated from rhizosphere and endo-rhizosphere of wheat grown in the mountain region (not previously explored) was examined and characterized through polyphasic approach. Based on morphological observations, we found two putative Bacillus sp. strains including one rhizospheric isolate AJK-4 and one endophytic isolate AJIK-8. Similarly, we found Stenotrophomonas sp. strains both in the rhizosphere (AJK-3) as well as endosphere (AJK-9) of wheat. The 16S rRNA sequence analysis of bacterial strain AJK-3 showed 99\% similarity with S. rhizophila type strain 


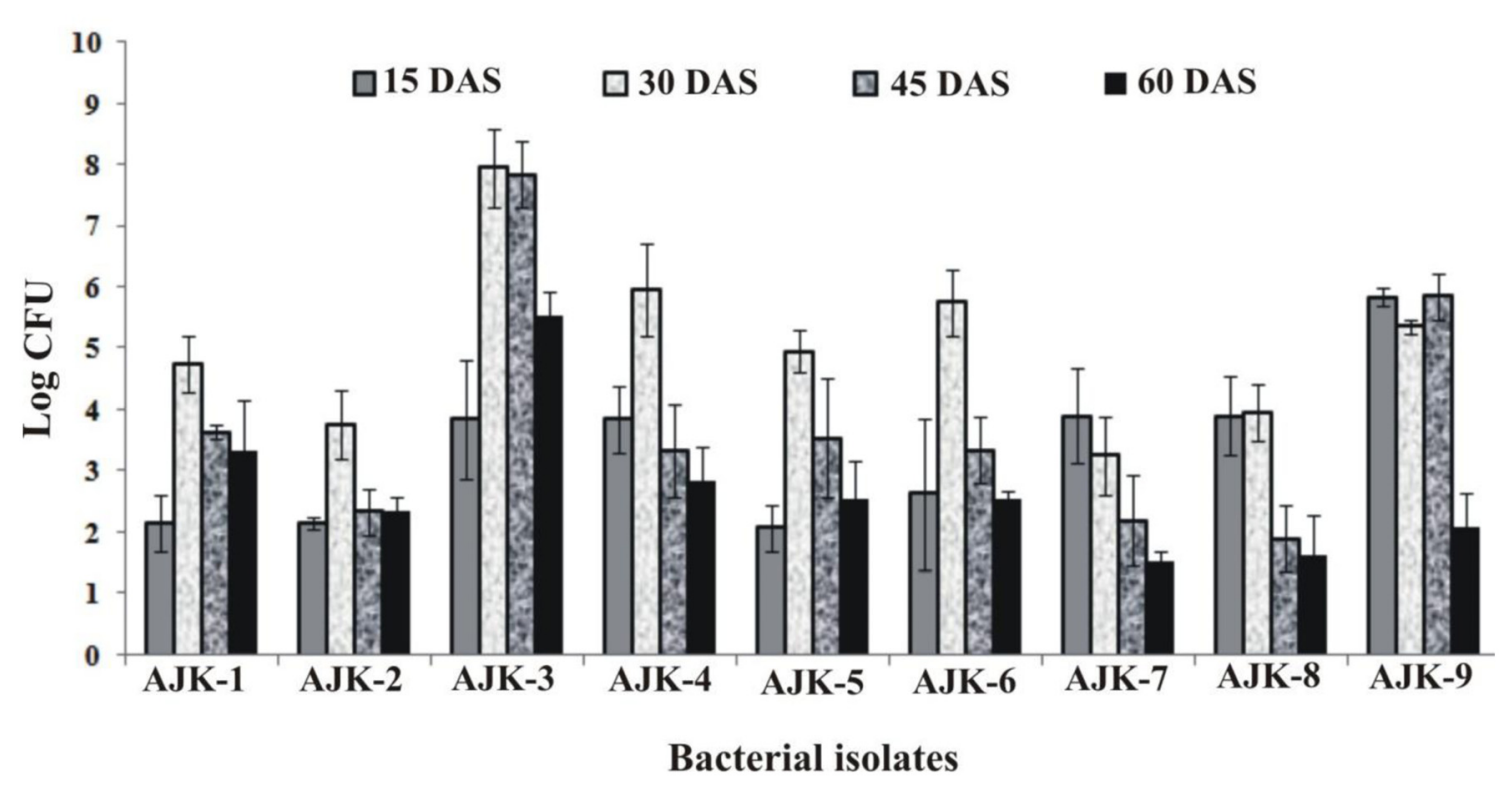

FIGURE 2 | Population density of different bacteria inoculated to wheat at different time intervals under axenic conditions. The error bars represent the least significant difference among treatments at $P \leq 0.05$.

TABLE 3 | Effect of bacterial isolates on the growth characteristics of wheat grown in pouches under axenic conditions.

\begin{tabular}{|c|c|c|c|c|c|c|}
\hline Treatments & $\begin{array}{l}\text { Shoot length } \\
\text { (cm) }\end{array}$ & $\begin{array}{l}\text { Shoot fresh weight } \\
\left.\text { (mg plant }^{-1}\right)\end{array}$ & $\begin{array}{l}\text { Shoot dry weight } \\
\left.\text { (mg plant }^{-1}\right)\end{array}$ & $\begin{array}{l}\text { Root length } \\
\text { (cm) }\end{array}$ & $\begin{array}{l}\text { Root fresh weight } \\
\left(\mathrm{mg} \mathrm{plant}^{-1}\right)\end{array}$ & $\begin{array}{l}\text { Root dry weight } \\
\left.\text { (mg plant }^{-1}\right)\end{array}$ \\
\hline control & 22.0 & 90 & 42 & 15.30 & 25 & 7 \\
\hline Er-20 & 18.61 & 82 & 51 & 15.58 & 18 & 9 \\
\hline AJK-1 & 23.3 & 105 & 43 & 19.73 & 35 & 14 \\
\hline AJK-2 & 26.0 & 129 & 68 & 22.15 & 42 & 16 \\
\hline AJK-3 & 27.0 & 109 & 49 & 20.85 & 36 & 19 \\
\hline AJK-4 & 24.57 & 118 & 53 & 20.83 & 47 & 14 \\
\hline AJK-5 & 23.20 & 111 & 54 & 20.63 & 41 & 17 \\
\hline AJK-6 & 24.49 & 108 & 52 & 21.20 & 38 & 15 \\
\hline AJK-7 & 23.69 & 10 & 67 & 20.77 & 39 & 15 \\
\hline AJK-8 & 23.46 & 117 & 52 & 19.36 & 51 & 17 \\
\hline AJK-9 & 23.40 & 135 & 61 & 19.13 & 49 & 11 \\
\hline $\operatorname{LSD}(P \leq 0.05)$ & 3.96 & 6.84 & 5.30 & 3.67 & 2.51 & 5.34 \\
\hline SEM & 1.34 & 12.0 & 8.0 & 1.25 & 13.0 & 1.4 \\
\hline
\end{tabular}

Control, non-inoculated, no bacterial inoculums but plants were provided with full strength Hoagland containing N and P nutrients; Er-20, Positive control strain; SEM, standard error of means; Data are the mean values of 10 replicates; LSD, least significant difference.

DSM 14405 which has been reported as a plant associated bacterium showing separate physiological and genetic cluster with low DNA-DNA hybridization value $(<50 \%)$ from clinical and environmental strains (Wolf et al., 2001). S. rhizophila strains are plant associated and have been isolated from the rhizosphere of oilseed rape and from the rhizosphere, and potato tuber. Endophytic colonization of this bacterium has also been reported along with its antagonistic activity against plant pathogenic fungi, e.g., Verticillium dahliae, Rhizoctonia solani, Sclerotinia sclerotiorum, and the human pathogenic fungus Candida albicans. The endophytic isolate AJK-9 showed 95\% similarity with Stenotrophomonas sp. and shared many of its beneficial characteristics resembling Stenotrophomonas strain
AJK-3. We found that both Bacillus and Stenotrophomonas are colonizers of wheat plant in the rhizosphere as well as root interior in that region. Endophytic strain AJK-7 was identified as Acetobactor pasteurianus. Acetobacter sp. are obligatory aerobic, nitrogen-fixing bacteria that are known for producing acid as a result of metabolic processes. Acetobacter diazotrophicus is also a plant endophyte and has been said to be capable of excreting about half of its fixed nitrogen in a form that plants can use. The study indicated that the biochemical tests of bacterial identification and characterization can only be used to some extent to discriminate among the bacterial strains, but could not distinguish among the closely related ones. While, full-length $16 \mathrm{~S}$ rRNA sequencing provides 
A
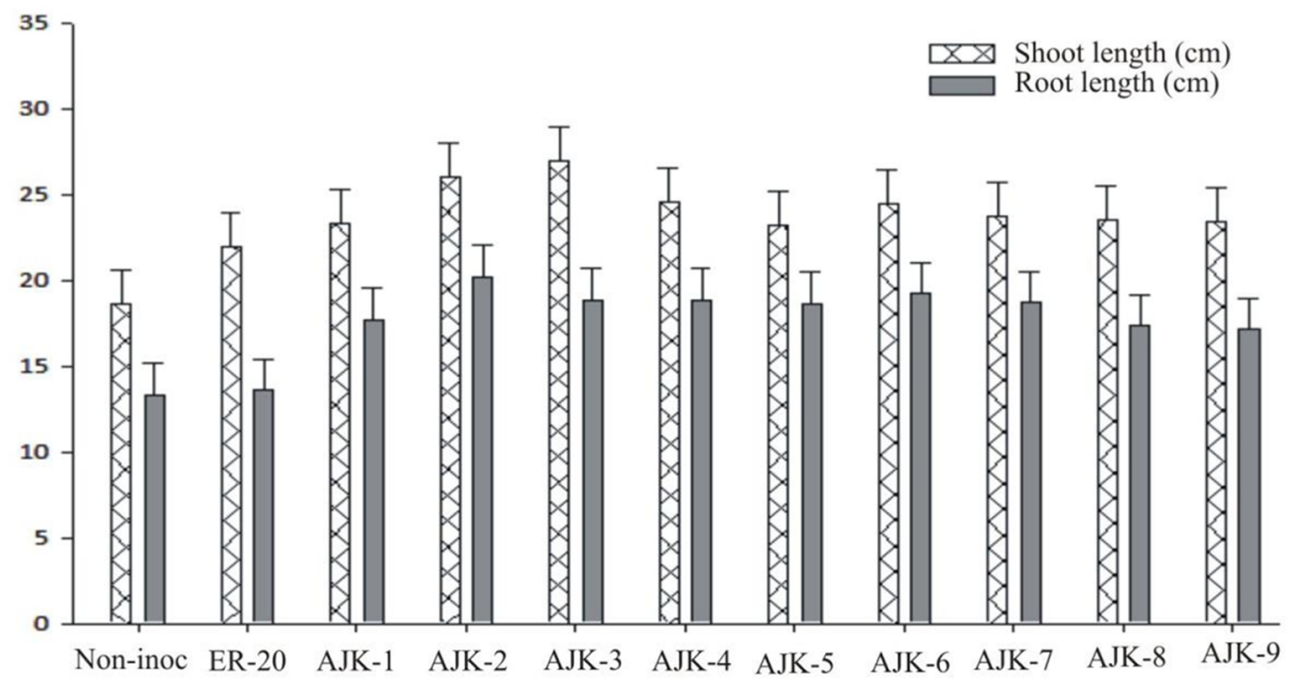

B

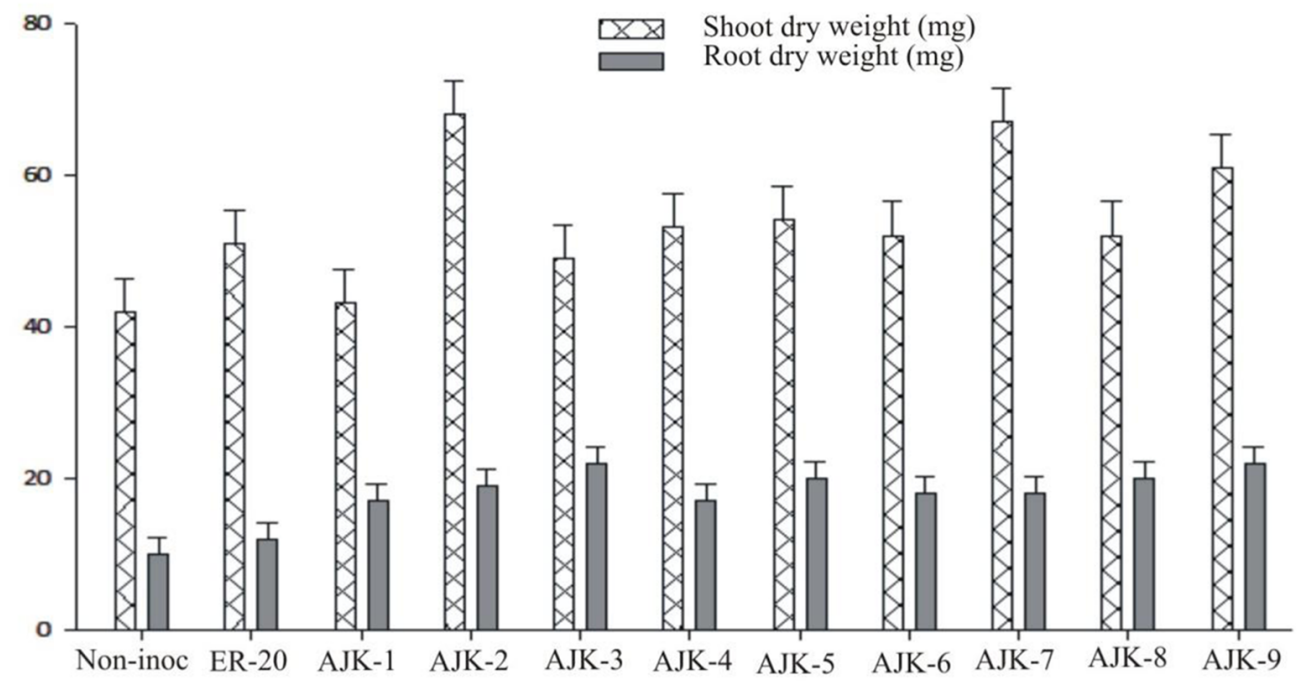

FIGURE 3 | Effect of PGPR inoculation on shoot and root length (A) and shoot/root dry weight (B) of wheat variety Inqlab grown in growth pouches under axenic conditions. The error bars represent the least significant difference among treatments at $P \leq 0.05$.

information regarding separate entity of each isolate from the wheat rhizosphere. Previous studies indicated I6S rRNA sequence analysis as an authenticated technique used to study bacterial isolates at species level (Imran et al., 2010; Alam et al., 2011).

In vitro screening for characteristics commonly associated with plant growth promotion revealed that seven bacteria were able to produce IAA in a range of $0.27-77.98 \mu \mathrm{g} / \mathrm{mL}$, indicating a substantial variability among rhizosphere and endophytic wheat isolates for IAA production. The potential of bacterial isolates to produce IAA indicates their ability to use as growth hormones or growth regulators. Our results were in agreement with the previous study where the PGPR from the rhizosphere of Brassica campestris had shown to produce
6.02-29.75 $\mu \mathrm{g} / \mathrm{ml}$ of IAA (Poonguzhali et al., 2008). The variation in the ability of PGPR to produce IAA found in the present study had also been reported earlier (Mansour et al., 1994; Zahir et al., 2000). This variation is attributed to the various biosynthetic pathways, location of the genes involved, regulatory sequences, and the presence of enzymes to convert active free IAA into conjugated forms (Patten and Glick, 1996). The production of IAA by bacteria isolated from rhizosphere of different crops, i.e., peanut, maize, wheat, and rice had already been reported in number of studies (Dey et al., 2004; Cakmakci et al., 2007; Mehnaz et al., 2010). The amount of IAA detected in the present study (with and without tryptophan) seems relatively higher than reported earlier, indicating that soils under investigation have bacteria that have the characteristics 
A
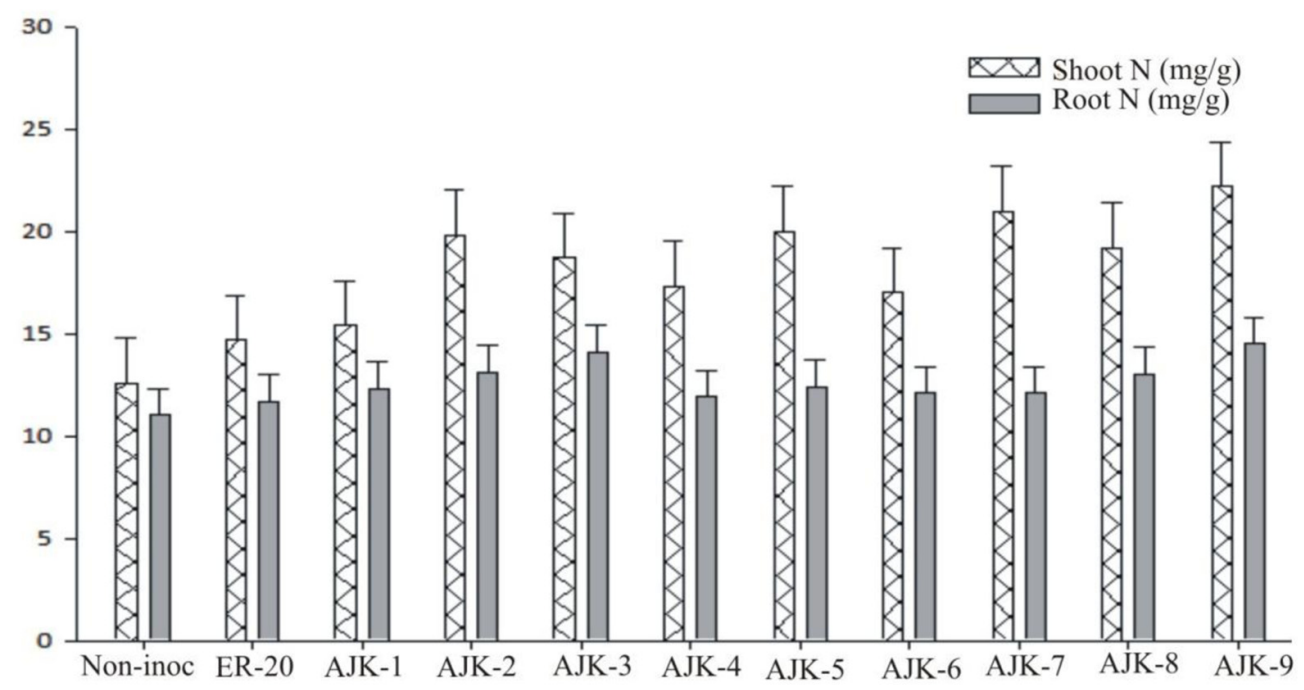

B

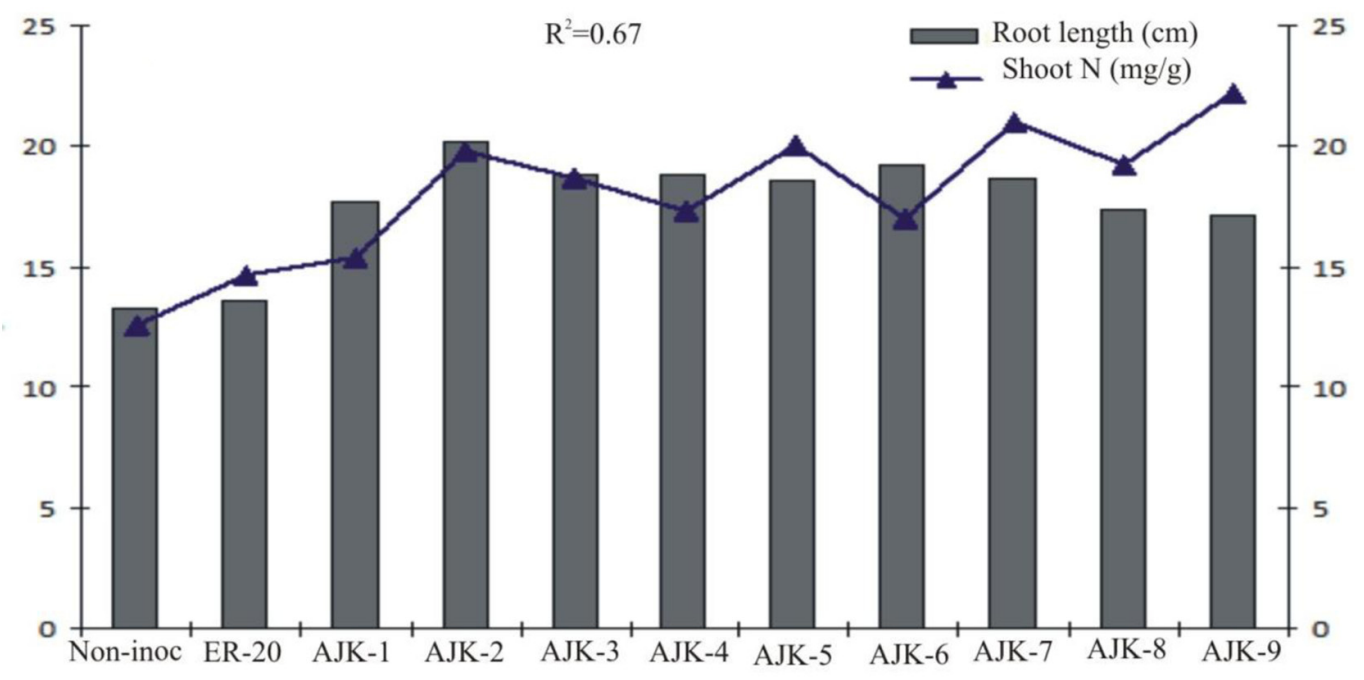

FIGURE 4 | Nitrogen contents $\left(\mathrm{mg} \mathrm{g}^{-1}\right)$ in shoots and roots (A) and relationship between shoot $\mathbf{N}$ contents vs. root length, the error bars represent the least significant difference (LSD) among different treatments at $P \leq 0.05$ (B) of PGPR-inoculated wheat variety Inqlab grown in growth pouches under axenic conditions.

most commonly sought for use in growth enhancement of plants.

The beneficial effect of PGPR in maintaining adequate levels of mineral nutrients especially the $\mathrm{P}$ in crop production had been previously reported (Rodriguez and Fraga, 1999; Saravanan et al., 2007). In our study, four bacterial isolates were found efficient solubilizer of phosphate. The ability of PGPR strains to solubilize insoluble $\mathrm{P}$ and convert it to plant available form is an important characteristic under conditions where $\mathrm{P}$ is a limiting factor for crop production. In two different studies, very limited number of P-solubilizers $23.5 \%$ of the total tested strains and five out of the 207 isolates) has been reported (Hameeda et al., 2006; Islam et al., 2010). The soil phosphate solubilizing strains can increase the availability of phosphorus to plant by mineralizing organic phosphorus compounds and by converting inorganic phosphorus into more available form (Bar-Yosef et al., 1999). Phosphate solubilization is mainly due to the production of microbial metabolites including organic acids which decreases the $\mathrm{pH}$ of the culture media (Puente et al., 2004; Sahin et al., 2004; Shahid et al., 2012). The presence of P-solubilizing microbial population in soils may be considered a positive indicator of utilizing the microbes as biofertilizers for crop production and beneficial for sustainable agriculture. The results of nitrogen fixation by ARA method indicated that fairly large population of wheat associated nitrogen fixers are present in the soils and can be beneficial to improve nitrogen nutrition of wheat and other crops. 
All the bacterial isolates significantly increased shoot and root length, shoot and root dry weight, and also enhanced the $\mathrm{N}$ contents of inoculated wheat seedlings. The plant growth promotion could be the result of the beneficial functions of applied PGPR isolates, like plant growth hormone production, nitrogen fixation, and $\mathrm{P}$ solubilization. As the inoculated plants were not supplied with any additional source of $\mathrm{N}$ or any form of soluble $\mathrm{P}$, the higher amount of $\mathrm{N}$ detected in the shoot or roots of inoculated plants as well as growth promotion may be attributed to the bacterial-assisted growth enhancement phenomenon. In addition to some other parameters positively influenced the growth of plant, auxin production by the isolates is proposed as a major means of attaining growth promotion (Deepa et al., 2010). Furthermore, the inoculation of PGPR having multi-functional traits is better than having single traits (Imran et al., 2014). IAA is involved in root initiation, cell division, cell enlargement, increases root surface area, and consequent access to soil nutrients by enhanced formation of roots (Dey et al., 2004; Gray and Smith, 2005). Auxin production has been proposed as a major means of attaining early growth promotion in wheat (Khalid et al., 2004) along-with P-solubilization (Rajput et al., 2013). The response of plants to different isolates was variable which may be attributed to their individual traits and rhizospheric competencies. Most of the bacteria showed good survival and persistence in the rhizosphere. The significant increase in growth and $\mathrm{N}$ level both in shoot and root upon isolates application is a clear indicative of the fact that the bacterial isolates have been able to provide better nutrient flux to the plant host which resulted in the increase of the plant biomass and

\section{References}

Ahmad, N., Johri, S., Abdin, M. Z., and Qazi, G. N. (2009). Molecular characterization of bacterial population in the forest soil of Kashmir, India. World J. Microbiol. Biotechnol. 25, 107-113. doi: 10.1007/s11274-008-9868-2

Alam, S. I., Bansod, S., Goel, A. K., and Singh, L. (2011). Characterization of an environmental strain of Bacillus thuringiensis from a hot spring in western Himalayas. Curr. Microbiol. 62, 547-556. doi: 10.1007/s00284-010-9743-x

Bar-Yosef, B., Rogers, R. D., Wolfram, J. H., and Richman, E. (1999). Pseudomonas cepacia - mediated rock phosphate solubilization in kaolinite and montmorillonite suspensions. Soil Sci. Soc. Am. J. 63, 1703-1708. doi: 10.2136/sssaj1999.6361703x

Cakmakci, R., Erat, M., Erdogan, U., and Dönmez, M. F. (2007). The influence of plant growth-promoting rhizobateria on growth and enzyme activities in wheat and spinach plants. J. Plant Nutr. Soil Sci. 170, 288-295. doi: 10.1002/jpln.200625105

Cavalcante, V. A., and Döbereiner, J. (1988). A new acid-tolerant nitrogen fixing bacterium associated with sugarcane. Plant Soil 108, 23-31. doi: 10.1007/BF02370096

Chahboune, R., Barrijal, S., Moreno, S., and Bedmar, E. J. (2011). Characterization of Bradyrhizobium species isolated from root nodules of Cytisus villosus grown in Morocco. Syst. Appl. Microbiol. 34, 440-445.

Deepa, C. K., Dastager, S. G., and Pandey, A. (2010). Isolation and characterization of plant growth promoting bacteria from non-rhizospheric soil and their effect on cowpea (Vigna unguiculata (L.) Walp.) seedling growth. World J. Microbiol. Biotechnol. 26, 1233-1240. doi: 10.1007/s11274-009-0293-y

Dey, R., Pal, K. K., Bhatt, D. M., and Chauhan, S. M. (2004). Growth promotion and yield enhancement of peanut (Arachishypogaea L.) by application of plant growth promoting rhizobacteria. Microbiol. Res. 159, 371-394. doi: 10.1016/j.micres.2004.08.004
$\mathrm{N}$ accumulation. The increase in root length due to the applied isolates may also contributed to increase $\mathrm{N}$ uptake in plant shoot as both the parameters were significantly correlated in the study $\left(R^{2}=0.67\right)$.

\section{Conclusion}

This is a basic study that has provided an insight into the bacterial community present in the mountainous region of Rawalakot, AJK, Pakistan. We have demonstrated efficient $\mathrm{N}_{2}$ fixing, P-solubilizing, and IAA-producing bacteria present among the natural population. These characteristics are considered as important PGP traits and have been found effective in positively improving the growth and $\mathrm{N}$ contents of tested wheat plants. These isolates offer potential in field applications as PGP agents in wheat. Further studies should be focused on the detailed molecular and functional characterization of these PGPR for practical applications in the field.

\section{Acknowledgments}

This research work was kindly supported by the National Institute for Biotechnology and Genetic Engineering (NIBGE), Faisalabad and the University of Azad Jammu and Kashmir, Pakistan. The authors are grateful to the technical staff of the Department of Soil and Environmental sciences, Faculty of Agriculture, Rawalakot-AJK for their technical assistance and help in collecting soil samples.

Glick, B. R. (1995). The enhancement of plant growth by freeliving bacteria. Can. J. Microbiol. 4, 1109-1114.

Gordon, S. A., and Weber, R. P. (1951). Colorimetric estimation of indoleacetic acid. Plant Physiol. 26, 192-195.

Gray, E. J., and Smith, D. L. (2005). Intracelluler and extracellular PGRP: commonalities and distinctions in the plant-bacterium signaling processes. Soil Biol. Biochem. 37, 395-412. doi: 10.1016/j.soilbio.2004. 08.030

Hameed, S., Yasmin, S., Malik, K. A., Zafar, Y., and Hafeez, F. Y. (2004). Rhizobium, Bradyrhizobium and Agrobacterium strains isolated from cultivated legumes. Biol. Fertil. Soils 39, 179-185. doi: 10.1007/s00374-0030697-z

Hameeda, B., Rupela, O. P., Reddy, G., and Satyavani, K. (2006). Application of plant growth-promoting bacteria associated with composts and macrofauna for growth promotion of pearl millet (Pennisetum glaucum L.). Biol. Fertil. Soils 43, 221-227. doi: 10.1007/s00374-006-0098-1

Hardy, R. W. F., Burns, R. C., and Holsten, R. D. (1973). Applications of the acetylene-ethylene assay for measurement of nitrogen fixation. Soil Biol. Biochem. 5, 47-81. doi: 10.1016/0038-0717(73)90093-X

Imran, A., Hafeez, F. Y., Frühling, A., Schumann, P., Malik, K. A., and Stackebrandt, E. (2010). Ochrobactrum ciceri sp. nov., isolated from nodules of Cicer arietinum. Int. J. Syst. Evol. Microbiol. 60, 1548-1553. doi: 10.1099/ijs.0.013987-0

Imran, A., Saadalla, M. J. A., Khan, S. U., Mirza, M. S., Malik, K. A., and Hafeez, F. Y. (2014). Ochrobactrum sp. Pv2Z2 exhibits multiple traits of plant growth promotion, biodegradation and $\mathrm{N}$-acyl-homoserine-lactone quorum sensing. Ann. Microbiol. 64, 1797-1806. doi: 10.1007/s13213-014-0824-0

Islam, M. R., Ahamed, R., Rahman, M. O., Akbar, M. A., Al-Amin, M., Alam, K. D., et al. (2010). In vitro antimicrobial activities of four medicinally important plants in Bangladesh. Eur. J. Sci. Res. 39, 199-206. 
Jeon, J. S., Lee, S. S., Kim, H. Y., Ahn, T. S., and Song, H. G. (2003). Plant growth promotion in soil by some inoculated microorganisms. J. Microbiol. 41, 271-276.

Keating, J. D., Beck, L., Materon, A., Yurtsever, N., Karuc, K., and Altuntas, S. (1995). The role of D.P rhizobial diversity in legume crops productivity in the west Asian Highlands. Exp. Agric. 31, 473-483. doi: 10.1017/S0014479700026454

Keeney, D. R., and Nelson, D. W. (1982). "Nitrogen-inorganic forms," in Methods of Soil Analysis, Part 2, Chemical and Microbiological Properties, eds A. L. Page, R. H. Miller, and D. R. Keeney (Madison, WI: SSSA), 643-693.

Khalid, A., Arshad, M., and Zahir, Z. A. (2004). Screening plant growth promoting rhizobacteria for improving growth and yield of wheat. J. Appl. Microbiol. 46, 473-480. doi: 10.1046/j.1365-2672.2003.02161.x

Khan, A. G. (2005). Role of soil microbes in the rhizospheres of plants growing on trace metal contaminated soils in phytoremediation. J. Trace Elem. Med. Biol. 18, 355-364. doi: 10.1016/j.jtemb.2005.02.006

Kumar, A., Maurya, B. R., and Raghuwanshi, R. (2014). Isolation and characterization of PGPR and their effect on growth, yield and nutrient content in wheat (Triticum aestivum L.). Biocatal. Agric. Biotechnol. 3, 121-128.

Laguerre, G., Mavingui, P., Allard, M. R., Charnay, M. P., Louvrier, P., Mazurier, S. I., et al. (1996). Typing of rhizobia by PCR DNA fingerprinting and PCRrestriction fragment length polymorphism analysis of chromosomal and symbiotic gene regions: application to Rhizobium leguminosarum and its different biovars. Appl. Environ. Microbiol. 62, 2029-2036.

Lucy, M., Reed, E., and Glick, B. R. (2004). Application of free living plant-promoting rhizobacteria. Antonie van Leeuwenhoek. 86, 1-25. doi: 10.1023/B:ANTO.0000024903.10757.6e

Maniatis, T., Fritsch, E. F., and Sambrook, J. (1982). Molecular cloning: A Laboratory Manual. New York: Cold Spring Harbor Laboratory, 45.

Mansour, F. A., Ildesuguy, H. S., and Hamedo, H. A. (1994). Studies on plant growth regulators and enzyme production by some bacteria. J. Qatar Univ. Sci. $14,81-288$.

Marques, A. P. G. C., Pires, C., Moreira, H., Rangel, A. O. S. S., and Castro, P. M. L. (2010). Assessment of the plant growth promotion abilities of six bacterial isolates using Zea mays as indicator plant. Soil Biol. Biochem. 42, 1229-1235. doi: 10.1016/j.soilbio.2010.04.014

Mehnaz, S., Kowalik, T., Reynolds, B., and Lazarovits, G. (2010). Growth promoting effects of corn (Zea mays) bacterial isolates under greenhouse and field conditions. Soil Biol. Biochem. 42, 1848-1856. doi: 10.1016/j.soilbio.2010.07.003

Mirza, M. S., Rasul, G., Mehnaz, S., Ladha, J. K., So, R. B., Ali, S., et al. (2000). "Beneficial effects of nitrogen-fixing bacteria on rice," in The Quest for Nitrogen Fixation in Rice, eds J. K. Ladha and P. M. Reddy (Los Baños: IRRI), 191-204.

Mirza, M. S., Waseem, A., Farooq, L., Jacqueline, H. B., Rene, N. P., and Malik, K. A. (2001). Isolation, partial characterization, and the effect of plant growth promoting bacteria (PGPB) on micro propagated sugarcane in vitro. Plant Soil 237, 47-54. doi: 10.1023/A:1013388619231

MSTATC. (1990). A Microcomputer Program for the Design, Management, and Analysis of Agronomic Research Experiments. East Lansing, MI: Michigan State University.

Murphy, J., and Riley, J. P. (1962). A modified single solution method for the determination of phosphate in natural waters. Anal. Chim. Acta 27, 31-36. doi: 10.1016/S0003-2670(00)88444-5

Narula, N., Kumar, V., Singh, B., Bhatia, R., and Laxminarayana, K. (2005). Impact of biofertilizers on grain yield in spring wheat under varying fertility conditions and wheat-cotton rotation. Arch. Agron. Soil Sci. 51, 79-89. doi: $10.1080 / 03650340400029382$

Okon, Y., Albercht, S. L., and Burris, R. H. (1977). Methods for growing Spirillum lipoferum and for counting it in pure culture and in association with plants. Appl. Environ. Microbiol. 22, 85-88.

Ozturk, A., Caglar, O., and Sahin, F. (2003). Yield response of wheat and barley to inoculation of plant growth promoting rhizobacteria at various levels of nitrogen fertilization. J. Plant Nutr. Soil Sci. 166, 262-266. doi: 10.1002/jpln.200390038

Patten, C., and Glick, B. R. (1996). Bacterial biosenthesis of indole-3-acetic acid. Can. J. Microbiol. 42, 207-220. doi: 10.1139/m96-032

Pikovskaya, R. I. (1948). Mobilization of phosphorus in soil in connection with the vital activity of some microbial species. Mikrobiologya 17, 362-370.
Poonguzhali, S., Madhaiyan, M., and Sa, T. M. (2008). Isolation and identification of phosphate solubilizing bacteria from Chinese cabbage and their effect on growth and phosphorus utilization of plants. J. Microbiol. Biotechnol. 18, 773-777.

Puente, M. E., Bashan, Y., Li, C. Y., and Lebsky, V. K. (2004). Microbial populations and activities in the rhizoplane of rock-weathering desert plants. I. Root colonization and weathering of igneous rocks. Plant Biol. (Stuttg.) 6, 629-642. doi: 10.1055/s-2004-821100

Rajput, L., Imran, A., Mubeen, F., and Hafeez, F. Y. (2013). Salt-tolerant PGPR strain Planococcus rifietoensis promotes the growth and yield of wheat (Triticum aestivum L.) cultivated in saline soil. Pak. J. Bot. 45, 1955-1962.

Rodriguez, H., and Fraga, R. (1999). Phosphate solubilizing bacteria and their role in plant growth promotion. Biotechnol. Adv. 17, 319-339. doi: 10.1016/S07349750(99)00014-2

Sahin, F., Cakmakci, R., and Kanta, F. (2004). Sugar beet and barley yields in relation to inoculation with N2-fixing and phosphate solubilizing bacteria. Plant Soil 265, 123-129. doi: 10.1007/s11104-005-0334-8

Saravanan, V. S., Madhaiyan, M., and Thangaraju, M. (2007). Solubilization of zinc compounds by the diazotrophic, plant growth promoting bacterium Gluconacetobacter diazotrophicus. Chemosphere 66, 1794-1798. doi: 10.1016/j.chemosphere.2006.07.067

Shaharoona, B., Naveed, M., Arshad, M., and Zahir, Z. A. (2008). Fertilizerdependent efficiency of Pseudomonads for improving growth, yield, and nutrient use efficiency of wheat (Triticum aestivum L.). Appl. Microbiol. Biotechnol. 79, 147-155. doi: 10.1007/s00253-008-1419-0

Shahid, M., Hameed, S., Imran, A., Ali, S., and van Elsas, J. D. (2012). Root colonization and growth promotion of sunflower (Helianthus annuus L.) by phosphate solubilizing Enterobacter sp. Fs-11. World J. Microbiol. Biotechnol. 28, 2749-2758. doi: 10.1007/s11274-012-1086-2

Somasegaran, P., and Hoben, H. J. (1994). Handbook for Rhizobia. Methods in Legume-Rhizobium Technology. Heidelberg, NY: Springer. doi: 10.1007/978-14613-8375-8

Steel, R. G. D., and Torrie, J. H. (1980). Principles and Procedures of Statistics, 2nd Edn. New York, NY: McGraw Hill Book Co. Inc.

Tan, Z., Xiao-Dong, X., En-Tao, W., Jun-Lian, G., Esperanza, M., and Wen-Xin, C. (1997). Phylogenetic and genetic relationships Mesorhizobium tianshanense and related Rhizobia. Int. J. Syst. Bacteriol. 47, 874-879. doi: 10.1099/0020771347-3-874

Tien, T. M., Gaskins, M. H., and Hubbell, D. H. (1979). Plant growth substances produced by Azospirillum brasilense and their effect on the growth of pearl millet (Pennisetum americanum L.). Appl. Environ. Microbiol. 37, 1016-1024.

Vincent, J. M., and Humphrey, B. (1970). Taxonomically significant group antigens in Rhizobium. J. Gen. Microbiol. 63, 379-382. doi: 10.1099/00221287-63-3-379

Weaver, R. W., and Frederick, L. R. (1982). "Rhizobium," in Methods of Soil Analysis, Part 2. Chemical and Microbiological Properties, eds A. L. Page, R. H. Miller, and D. R. Keeney (Madison, WI: SSSA), 1043-1067.

Wolf, Y. I., Rogozin, I. B., Grishin, N. V., Tatusov, R. L., and Koonin, E. V. (2001). Genome trees constructed using five different approaches suggest new major bacterial clades. BMC Evol. Biol. 1:8. doi: 10.1186/1471-2148-1-8

Zahir, A., Abbas, S. A., Khalid, M., and Arshad, M. (2000). Structure dependent microbially derived plant hormones by improving growth of maize seedlings. Pak. J. Biol. Sci. 3, 289-291. doi: 10.3923/pjbs.2000.289.291

Zhang, J., Liu, J., Meng, L., Ma, Z., Tang, X., Cao, Y., et al. (2012). Isolation and characterization of plant growth-promoting rhizobacteria from wheat roots by wheat germ agglutinin labeled with fluorescein isothiocyanate. J. Microbiol. 50, 191-198. doi: 10.1007/s12275-012-1472-3

Conflict of Interest Statement: The authors declare that the research was conducted in the absence of any commercial or financial relationships that could be construed as a potential conflict of interest.

Copyright $\odot 2015$ Majeed, Abbasi, Hameed, Imran and Rahim. This is an open-access article distributed under the terms of the Creative Commons Attribution License (CC BY). The use, distribution or reproduction in other forums is permitted, provided the original author(s) or licensor are credited and that the original publication in this journal is cited, in accordance with accepted academic practice. No use, distribution or reproduction is permitted which does not comply with these terms. 